Yayın Geliş Tarihi: 07.04.2020

Yayına Kabul Tarihi: 04.04.2021

Online Yayın Tarihi: 30.06.2021

http://dx.doi.org/10.16953/deusosbil.716105
Dokuz Eylül Üniversitesi

Sosyal Bilimler Enstitüsü Dergisi

Cilt: 23, Say1: 2, Y11: 2021, Sayfa: 833-852

ISSN: 1302-3284 E-ISSN: 1308-0911

Araştırma Makalesi

\title{
ADALET AĞAOĞLU'NUN 12 MART DÖNEMİ ÖYKÜLERİNDE SUÇ KAVRAMI
}

$\ddot{O} z$

Esra DICLE*

Adalet Ağaoğlu, özellikle 1970 'lerde yazdiğı öykü, tiyatro oyunu ve romanlarında, 12 Mart döneminin politik ortamına, psikolojik-fiziksel şiddet olaylarına, toplumsal çatışmaya, kutuplaşmaya, işkence gerçeğine, sosyalist öznenin bütün bunlar arasında yaşadiğl suçluluk duygusuna, iç ve diş çelişkilere odaklanır. Adalet Ăgaoğlu, bu dönemde yazdiğı öykülerinde, suç olgusunu, kanunları belirleyenlerin meşruiyetini tartışmaya açar, kanunlar tarafindan suçlu ilan edilenlerin masumiyetini sergiler. Bu dönemde yazdĭ̆ Yüksek Gerilim (1974) kitabında, 12 Mart dönemi askerî yönetimiyle devrimci aktivistler arasındaki çatışma yansıtılırken aynı zamanda kapitalist-burjuva devletinde işçi-emekçilerin yaşadı̆̆ ekonomik şiddet ve onları suça iten koşullar da ele alınır. Böylece hem politik hem adi suç tanımlamaları etrafında suç olgusunun sınıfsal bağlamı sorgulanır. Sessizliğin İk Sesi (1978) öykü kitabındaysa, 12 Mart döneminin sıcak-çatışmalı ortamından uzaklaşılmasının da etkisiyle yazar, suç olgusunu daha örtük bir bağlamda, ă̆ırlıklı olarak sivil yaşamdaki sınıf çatışmaları odağında ele alır. Bu yazıda, Adalet Ăgaoğlu'nun iki öykü kitabında, suç konusuna hangi meseleler odă̆ında yaklaştı̆̆ını ele almaya çalışacă̆ım.

Anahtar sözcükler: Suç, 12 Mart, Öykü, Adalet Ağaoğlu.

\section{THE NOTION OF “CRIME” IN THE STORIES OF ADALET AĞAOĞLU ON MARCH 12 PERIOD}

\begin{abstract}

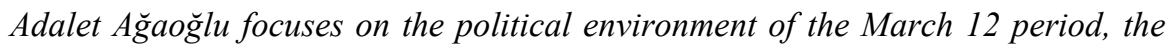
psychological-physical violence events, social conflict, polarization, the reality of torture, a socialist subject's feeling of guilt, and its internal and external contradictions among all these, in her stories, theater plays and novels written in the 1970s. In her stories written at this period, she discusses the phenomenon of crime, legitimacy of those who set the laws and

Bu makale için önerilen kaynak gösterimi (APA 6. Sürüm):

Dicle, E. (2021). Adalet Ağaoğlu'nun 12 Mart dönemi öykülerinde suç kavramı. Dokuz Eylül Üniversitesi Sosyal Bilimler Enstitüsü Dergisi, 23 (2), 833-852.

* Dr. Öğr. Gör., Boğaziçi Üniversitesi, Fen Edebiyat Fakültesi, Türkçe Dersleri Koordinatörlüğü, ORCID: 0000-0001-5029-4164, esradicle@gmail.com.
\end{abstract}


displays the innocence of those who are declared guilty by the laws. In her story book Yüksek Gerilim (1974), the conflict between the military administration and the revolutionary activists of the March 12 period is reflected, while at the same time discussing the economic violence faced by workers and laborers in the capitalist-bourgeois state and the conditions that pushed them into crime. Thus, the class context of the crime phenomenon is questioned around both political and ordinary crime definitions. In the other story book, Sessizligin Illk Sesi (1978), she deals with the phenomenon of crime in a more implicit context, mainly in the -context of class conflicts in civilian life, with the influence of the decrease on the hot-conflict environment of the March 12 period. In this article, I will try to show how Adalet Ağaoğlu focuses on the matter of crime in her two story books.

Keywords: Crime, Story, March 12, Adalet Ăgaoğlu.

\section{GIRIŞ}

Suç, en genel tanımıyla, topluma zarar verdiği ve tehlikeli olduğu kurallar ve kanunlar tarafından kabul edilen ve belirtilen eylem ve davranışlardır. Kanunlar ve toplumsal kurallar, insanlar toplu olarak yaşadıkları için var olmuştur. Bunların amacı kurulu düzeni korumaktır. Herhangi bir nedenle kanun ve kurallarla korunmuş düzenin dışına çıkanların adı suçlu ya da günahkâr, kanun dışına çıkan eylem ve olgular da suç veya günah sayılır. Söz konusu düzeni belirleyense kanun koyucudur. Suç ve ceza, kanun koyucunun kimliğine bağlı olarak tanımlanır. (Sağlık, 2009, s. 65) Neyin suç olarak kabul edilmesi gerektiği, toplumun kendi çıkarları doğrultusunda tanımlanır, bu nedenle suç, doğal değildir. Foucault'a göre, suçun tanımı ile suç ve ceza arasındaki bu keyfiyetin örtülmesi için, "cezalandırma sanatı, koskoca bir tasarım teknolojisine dayanmak zorundadır." (Foucault, 1992, ss. 129130)

$\mathrm{Bu}$ nedenle belirli bir çağ, dönem ve/ya toplumda suç unsuru oluşturan eylemler, bir başka kanun koyucunun hâkimiyetindeki bir başka çağ, dönem ve/ya toplumda aynı şekilde değerlendirilmeyebilir. Toplumların sosyal değişim ve gelişim süreci içinde de suç tanımı değişebilir. Bu nedenle suç evrensel bir olgu olduğu kadar, göreceli bir olgudur da.

Bireyin, planlı ya da plansız, bireye, topluma ve devlete karşı işlediği suçlardan, suçu işleyenin cinsiyet, rrk, siyasi görüş gibi niteliklerine kadar pek çok konu edebiyatı ilgilendirir. Suçun kaynağını bireyin mizacında bulan yaklaşım da toplumsal yapıda bularak suçu modern bireyin kendisini ifade etme aracı olarak gören bakış açısı da edebiyatın kendi sahası içinde değerlendirilir. (Erdoğan, 2011, s. 5) İnsanın suçu hazırlayan koşullarla imtihanı ve onu suça zorlayan şartlardaki tutumuyla ortaya çıkan trajedi, suç edimi üzerinden bütün bir hukuk sisteminin tarihsel çarpıklığı, hukuk sisteminde temsil edilen bütün bir toplumsal düzenin barındırdığı çelişkiler, yargılama ve hapsetme pratiklerinin sorunları, Sefiller, Suç ve Ceza, Savaş ve Barış gibi pek çok önemli eserde ele alınmış, edebiyat için her zaman 
önemli olmuştur. Suç insanın varoluşsal gerçekliğine, kendisiyle ve diş dünyayla yaşadığı çatışmaya içkindir. Edebiyat da suçu inceleyerek insanın zorlayıcı koşullar altındaki gerçekliğini ve dramını irdeler.

12 Mart 1971 muhtırasıyla sonuçlanan süreç ve sonrasında yaşanan ekonomik, toplumsal ve siyasi gelişmeler, Türk edebiyatında, hemen muhtıra sonrası dönemden başlayarak pek çok yönüyle ele alınmıştır. Bu metinlerde, devrimciler ile iktidar arasındaki çatışma, bunun topluma ve bireyler arası ilişkilere yansımaları, mevcut iktidarın uygulamaları, işkence sorunu, hapishane koşulları, psikolojik ve fiziksel, toplumsal ve bireysel şiddet ve çatışmanın boyutları tartışılmıştır.

Adalet Ağaoğlu'nun 1974 yılında yayımlanan ve dokuz öyküden oluşan Yüksek Gerilim ${ }^{l}$ adlı öykü kitabı ile 1978'de yayımlanan ve 12 öyküden oluşan Sessizliğin İlk Sesi ${ }^{2}$ öykü kitapları da söz konusu sürecin yansımalarını ele alır. Suçun tanımı, değişkenliği, suçu belirleyen temel etken olarak çevresel faktörlerin ele alınması, adi ve siyasi suçlu tanımlarının irdelenmesi, mevcut yasaların ve bu yasaları koyan iktidarın meşruiyeti, işkence sorunu, suçluluk duygusu gibi pek çok mesele, bu öykülerde sorunsallaştırılır. Bu yazıda öyküleri suç olgusunu ele alışı, hapishane ve işkence konusuna bakışı ve suçluluk duygusunu irdeleyişi üzerinden inceleyeceğim.

\section{"YAPANA DEĞIIL YAPTIRANA BAK", SUÇ EKONOMIYE İÇKINDDIR}

Marksist düşünce paralelinde oluşturulmuş kurmaca eserlerde pek çok konu suç ile ilgilidir. İlk olarak suç, sınıflı toplumun bir ürünü olarak incelenir. Buna göre belli bir sosyal yapıdaki sınıf ilişkileri değiştiğinde suç kalıpları da değişmektedir. Marx mevcut düzeni, suçluları suç işlemeye teşvik eden sosyal koşullar içine yerleştirdiği için eleştirir. Alman sosyal demokratı Willem A. Bonger, kapitalizmin rekabetçiliğinin egoizmi artırdığını iddia ederek kapitalizm ve suç arasındaki ilişkiyi irdeler. Toplumsal olarak zararlı egoist davranışlar bütün sınıflarda görülmesine rağmen politik güç, yöneten sınıfı en azından suçlu olarak itham edilmekten korur. Bu nedenle işçi sınıfının payı suç istatistiklerinde abartılır. Suçun daha yeni Marksist analizleri, yönetilen sınıflar arasındaki suçluluğu sınıf baskısına karşı adaptasyon veya direnme olarak; yöneten sınıfın suçluluğunu ise sınıf baskısının aracı olarak anlamaya çalışır. (Marksist Düşünce Sözlü̈̆̈̈, 2005, s. 558)

Adalet Ağaoğlu, roman ve hikâye yazarlığına 12 Mart döneminde başlayan Adalet Ağaoğlu, bu dönemin siyasal, toplumsal ve ekonomik meseleleriyle ilgilenen,

\footnotetext{
${ }^{1}$ Adalet Ağaoğlu, Yüksek Gerilim, İstanbul: İletişim Yayınları, 2004. Bu yazıda kitaptan yapılan alıntılar bu baskıya ait olacak ve yazı içinde parantezle gösterilecektir.

${ }^{2}$ Adalet Ağaoğlu, Sessizliğin İlk Sesi, İstanbul: Alkım Yayınları, 2004. Bu yazıda kitaptan yapılan alıntılar bu baskıya ait olacak ve yazı içinde parantezle gösterilecektir.
} 
toplumcu gerçekler metinler ortaya koyar. Bunu yaparken, roman ve hikâye türünün biçimsel ve estetik unsurlarını geliştiren, yenilikçi denemeler de yapar. Ağırlıklı olarak politik-ideolojik tutumları ve söylemleri baskın olan, genel olarak sosyalizmin açıklamalarını özel olarak 12 Mart sürecinde solun deneyimlerini anlatan metinlerin bulunduğu bir ortamda, insanın bireysel deneyimine, psikolojik süreçlerine; bilinç akışı, iç monolog, çağrışım gibi yöntemlerle 1şık tutar.

Adalet Ağaoğlu'nun ilk öykü kitabı olan Yüksek Gerilim'de yer alan öyküler; sınıflaşmanın tarihini ve güncel görünümlerini, 1970'lerin çatışmalı ortamını, yer yer gerçeklik düzleminde yer yer ironik ve alegorik bir biçimde sergiler. Hemen her birinde farklı anlatım tekniklerinin denendiği bu öykülerde yazar, düşünsel olanla estetik olanı birlikte geliştirir. Yazarın keskin gözlemciliği, eleştirel tutumu, doğanın, insanın ve tarihin hareketini kavrayışıyla, politik içeriğin estetize edilmesi; öykülerin kuvvetini artırır.

Adalet Ağaoğlu'nun bu öykülerinde, çevre, sınıf, konu, mekân farklılıklarına rağmen tüm öykü kişilerini birbirine teğelleyen unsur, suç olgusudur. Öykülerde suç kavramı, sınıflı toplumun, kapitalizmin toplum yapısında meydana getirdiği dönüşümlerin bir sonucu olarak ele alınır. "Yüksek Gerilim” adlı öykü de mevcut düzenin ortaya çıkardığı çatışmaların boyutlarını tartışır. Öykü, kalkınmanın bir göstergesi sayılan sanayi teknolojisi ve makineleşmeyle birlikte, doğanın tüm canlılarıyla nasıl zehirlendiğini, yok edildiğini ve yerini nasıl yapay, ölümcül bir düzenin aldığını göstererek başlar. "Tek pervaneli uçakların attığı ilaç, pamuk fidanları üstünde kurudu; damarlı yüzlerinde benek benek beyaz lekeler bıraktı.

(. . .) Kanallar suyun fazlasını denize akıttıkça, otların payına düşen nem de azaldı.

Yaz boyu azaldı bu pay ve otlar kurudu, dikene sardı. (. . .) Kanallar, ovadan çektikleri fazla suyun yüklendiği sivrisinek ölülerini de denize akıttılar.” (s. 7-8) Bir kameranın geniş plandan dar açıya doğru geçerek, gökyüzünden yeraltı sularına doğru inen, hareketli bir planla sergilediği doğanın dönüşümü, görüntüleme tekniğiyle, biraz da Brechtyen bir teknikle bir yabancılaştırma etkisi sağlar okura. Okura, üretim biçimlerinin ve araçlarının değişimini, tarımsal üretimin terk edilmesi ve sanayi üretimine geçilmesini, bu yolla doğanın, insanın, yaşamın zehirlenişini sinematografik bir dil ve mesafeyle yansitır.

Şantiyede süren çalışmalarda, sık sık az zamanda çok kanalet döşemenin önemi, yüksek gerilim hattının gölgesinde ve gözetiminde, oldukça riskli ve tehlikeli şartlarda süren üretimin hızı vurgulanır. "Treylerde kalan son kanalet de az sonra yüksek gerilim hattının toprakta bıraktığı yayvan gölgeyi bıçkı gibi kesecek. Kesip taa ötelere uzanacak. Uzanan her fazla metresi, kanalet döşeme ekibinin her biri için birer öğün demek olacak.” (s. 21) 




Yüksek gerilim hatt1, bütün olan biteni sessizce izleyen; denetimi sadece fark edildiği yerde değil, görülmediği yerlerde de süren bir güç gibi tanımlanır. "Geçtiği her yerde kendisiyle kesişen her şeye ve herkese güçlü adını kazıdı, bıraktı. Ama oralara uzanmadan önce yüksek gerilim hattı, geçtiği yerlerde hiçbir katı cismin kendisine elli santimden daha yakın gelmesine izin vermedi. (. . .) Dokunulmazlığını böylece koruyarak yürüdü, gitti ve milyarda bir gücünden çok daha, ama çok daha azını, vinç operatörü Kadir Çiçek'in ot-sap tavanından sarkan yirmi beş mumluk ampulüne boşalttı. (s. 9)

Burada sözü edilen yüksek gerilim hattı, gücünün soyut olması ve muhatap alınamazlığından alan modern iktidar biçimini temsil eder. Bu iktidar, dokunulmaz egemenlik alanına müdahale edilemez, gözetleyen, denetleyen, yargılayan, cezalandıran, ölümcül bir iktidardır. Yüksek gerilim hattı bu hâliyle iktidarın görünür ama varlığının kanıtlanamaz olduğu ilkesini hatırlatır. Foucault'ya göre bireylerin sürekli "gözlem altında" olmaları gerektiği fikri, bahsettiği üç iktidar türünden (diğerleri egemen iktidar ve biyoiktidardır) biri olan disiplinci iktidarın doğal bir parçasıdır; zira disiplin dışsal olarak "uysal bedenler"in davranış düzenliliği içinde oluşur. (Foucault, 2000, ss. 78-79) Modern öncesi dönemde sıradan insanlar üzerinde uygulanan güç, heybetinden, haşmetinden ve servetinden korkularak ve hayran kalınarak etkili olurken, modern dönemde ise, aynı güç seyredilmek yerine insanları seyrederek gölgede ya da kuytuda kalmayı tercih eder. ${ }^{3}$ Yüksek gerilim hattı, çalışma alanında tüm heybetiyle görünür ve bir tehdit, tehlike, ona göre tavır alınması ve asla alanına girilmemesi gereken bir güç oluştururken, hâkimiyeti sadece görünür olduğu alanda kalmaz, tüm haşmetiyle görünür olmadığ 1 yerleri de gücünün çok çok azını harcayarak gözetleyebilir.

Kadir Çiçek, ekonomik sıkıntılardan dolayı, istemeye istemeye yaşını büyülterek şantiyede çalışmasına izin verdiği kardeşi Hasan ile birlikte hava kararmış olmasına ve şantiye mühendisinin ikazlarına rağmen, tüm iyi niyet ve enerjileriyle -aslında bir an önce işi tamamlayarak evlerine buzdolabı alacak parayı denkleştirebilmek için- hattın son kanaletini döşemek, "zaman kaybetmemek için" çalışmaya devam ederler. Fakat yüksek gerilim hattı en ufak bir dikkatsizliği affetmeyecektir: "Kanaleti taşıyan askılardan biri kaymış, kanaletin bir ucu yere vurmuştu. Bozulan denge, o anda ağırlığından kurtulan vinç bumunu yukarı doğru esnetti. Yukarı doğru esneyen bum, yüksek gerilim hattının egemenlik alanına girdi;

\footnotetext{
${ }^{3}$ Foucault bu konuyu tartışmak için J. Bentham'ın tasarladığı Panoptikon hapishane mimarisini temel alır. Bu mekânı Foucault, disiplinci iktidarın metaforu olarak kullanır çünkü Panoptikon, iktidarın görünür ama teşhis edilemez olmasının somut temsilidir. "Görünür: tutuklu gözünün önünde sürekli olarak, gözlendiği merkez kulesinin siluetini bulacaktır. Varlığının kanıtlanamaz olması: tutuklu o anda kendine bakılıp bakılmadığını asla bilmemeli, ama bunun her ana olabileceğinden hiçbir kuşkusu bulunmamalıdır.” (Foucault, 1992, s. 253)
} 
gücünün milyarda birinden pek azını kapıp elinde hâlâ çelik halatı tutmakta olan Hasan'ın gövdesine akıttı. Çelik halat ucunda iri, siyah bir kömür asılıp kaldı." (s. 26)

Yüksek gerilim hattı, egemenlik alanına giren Hasan'1 yok ettiği gibi Kadir'i de hapsedecektir. Kadir, kardeşini sahte belgelerle işe aldığı için suçludur. Sorgulayan, yargılayan, cezalandıran iktidar tarafından kurban edilmiş, suçlu bulunmuştur. "Demek iş kazası?" dedi aracın içindeki öbür polis. "Sigortanız vardır. Kaza ise iyi. Kardeşininki sana kalır." Kuşkuyla baktı Kadir Çiçek'e. "Yaşı uygun ki çalıştı. Vardır sigortası kardeşinin de.” Hasetle baktı Kadir Çiçek’e. (s. 27)

Düzen için dava kapanmıştır. Gözlem, denetim, normalleştirme, uysallaştırma süreci devam etmektedir. İktidarın olmadığı yer, ideolojinin "dışarısı" yoktur. "Yüksek gerilim hattı (...) dokunulmazlığını koruyarak, büyük kentlerin kapılarında bölünüp kollara ayrılarak, caddelerde yeniden kollara ayrılarak, dış mahallelerde daha ince kollara ayrılarak ayrılan en ince kollarından birini Kadir Çiçek'in ot-sap tavanından aşırtarak gitti, gücünün milyarda birinden çok daha azını bir kez daha parçalara böldü ve böldüğü daha küçük çaplı güçleri cezaevlerinde durmadan çoğalan koğuşlara, o koğuşların tepelerindeki en küçük ampullere boşalttı." (s. 28)

Yüksek gerilim hatt1, bir yandan "somut" olarak güçlü ve heybetli varlığıyla her zaman korku uyandıran, bu sayede düzenin sorunsuz işlemesini sağlayan, egemenlik alanına yapılacak en küçük bir ihlali affetmeyen iktidarı tanımlarken, bir yandan da "soyut" olarak, gündelik hayatın kılcallarına sızan, örülerek değil gözleyerek varlığını koruyan, gücünü fark edilmemekten hatta yok sanılmaktan alan modern iktidar biçimlerini ifade eder.

Aynı kitaptaki "Bileyici" adlı öyküde de suç eylemi, suçu oluşturan etkenlerle birlikte tartış1lır. Öykü, önce ekonomik sistemlerin değişmesiyle birlikte sosyal yaşamın değişen yüzlerini detaylıca anlatır. Hem özel alanı hem kamusal alanı kapsayan, mimariden şehir planlamasına, meslek seçimlerinden yeme-içme, k1lık kıyafet alışkanlıklarına kadar her alanı etkileyen bu dönüşüm; değişen değer yargılarıyla birlikte sınıflı toplumun yeni bir şekil almasını, sınıflar arası çatışmayı, göç ve yoksulluk gibi sorunları, düzene uyanın uymayan üzerinde kurduğu baskı ve şiddeti beraberinde getirir. "Yüksek Gerilim" öyküsünde görülen Brechtyen tarihselleştirme ve yabancılaştırma tekniği, burada da görülür: "Eski sahipleri attar, baharatçı ve bakırcı olan üç evin oğulları da önceleri yine attar, baharatçı ve bakırcı oldular. Sonraları, onların oğullarının oğulları toptancılık, eczacılık ya da antikacılık ettiler. Bu dönemde aileler küçüldü. Evlerinde büyük oğullar ve onların kanlarıyla çocukları yaşadılar. Toptancılık, eczacılık ya da antika eşya satıcılığı edenlerin oğulları, bir süre sonra artık memur, doktor ve antika eşya kaçakçısı oldular." (s. 155) 


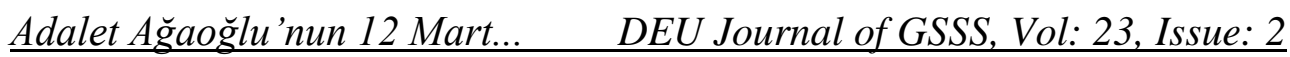

Yaşadığ1 köyde sanayinin, yapılaşmanın, makineleşmenin yayılma sahasından kurtulamayan bıçakçı Süleyman, zamanla kaçakçıların bölgeye daha ucuz, daha çeşitli bıçaklar getirmeye başlamasıyla, önce büyük et bıçakları yapmayı bırakır, sonra mangal, maşa ve kürek yapmayı. Bir zaman sonra sadece kalaycılık yapabiliyordur artık. Kendine güvenini kaybeden ve hepsi bir elden çıkma gibi duran, her yerde çokça bulunabilen kamalar, bıçaklar, testerelerle rekabet edemeyen Süleyman, kendisine bir bileyi makinesi yaparak geçimini sağlamaya başlar. Oğlu Ramazan'a bıraktığı tek şey bu olacaktır ve Ramazan da şehre göç ettiğinde en iyi bildiği işi sürdürmeye çalışır.

Bir gün, ince, gevşek asfaltla kaplanmış dar sokakta, iki yeni, yüksek betonarme bina arasında kalmış ve yıkılmaya yüz tutmuş eski bir ahşap evden yaşlı bir el uzanır Ramazan'a ve makaslarını bilemesini ister. Ramazan sessiz ama hevesli ve becerikli hareketlerle makasları bileylerken, gümbürtüyle gelen bir arabadan inen "taşeronluktan gelme bir müteahhit" bileyiciyi taciz etmeye başlar. Mesele, ya da bahane, park sorunudur: "İki tekerimi şuraya çıkarmadan park edemiyorum, sen buraya postunu sermişsin (. . .) Hem bu yaptığın iş mi? Kaç paralık iş? Adam utanır. Cız cız da cız cız. Kaç para getirir bu adama? (. . .) Ne söz anlamaz herifsiniz yahu? Bundan adam olmazsınız işte. Başınızın dikine gitmekten. Çekil dediler mi çekileceksin. Senin neden bileyicilik ettiğin belli zaten. Dikbaşl1lı̆̆ından. (. . .) Bileyicilik yapmaya utanmıyor musun? (. . .) Çocuk bile tenezzül etmez senin şu iş diye tuttuğun zırıltıya..." s. 167-168)

Bileyici kibarlıkla alttan almaya çabalarken müteahhitin gittikçe artan ses ve hakaret tonu, müteahhit gibilerin bileyici gibiler üzerinde kurduğu iktidarın, tahakkümün, baskının gösterisidir. Bileyici, müteahhitin evinin önünde durarak onun egemenlik alanına girmiştir ve hemen haddinin bildirilmesi gerekir. Müteahhit, sırtını dayadığı düzenden aldığ 1 "adam etme" yetkisiyle, düzenin çok para kazanmaya mecbur eden söylemini reddederek bir anlamda pasif itaatsizlikte bulunan kişiyi ıslah etme görevine soyunur. Otoritesinin onaylanmamasından, sözlerinin ciddiye alınmamasından dolayı sinirlenen müteahhit, baskısını daha da artırır. Bileyici, "Yaptığın işten utanmıyorsun, çocuklarından utan bari!" (s. 171) sözünden sonra "Başka nasıl düşünebilirim çocuklarımı?" (s. 172) diyerek kontrol etmeye çalıştığı öfkesini sonunda serbest bırakır ve elindeki bıçağı müteahhitin göğsüne iki defa saplar. Öykü, akış içinde çatışmanın ve gerilimin artırıldığ 1 , Bileyici'nin tepkisinin biriktirilerek son sahnede ortaya çıkartıldığı, sınıfsallığın, ekonomik olanın psikoloji-yoğun bir odaklanmayla anlatıldığı bir kurguya dayanır. Öykü boyunca, "Yüksek Gerilim" öyküsünde olduğu gibi, adım adım son sahne hazırlanır.

Müteahhit ile bileyici arasındaki çatışma, ekonomik düzenden kaynaklanan bir sınıf çatışmasının temsilidir. Bileyicinin müteahhiti öldürmesiyse, egemenin 
temsilcisi üzerinden egemen olana yöneltilmiş -bilinçsiz- bir tepkidir. Foucault'un deyimiyle dışlanmış özneler arasında sayılan suçluların ortak noktası egemen olana yönelmeleridir. Ama pek çoğu egemen olanın, dayatılan, sınırlanmış hayat olduğunu göremeyecek kadar ideolojik donanımdan da yoksundur. Bu nedenle suça kaynaklık eden şiddetlerini egemeni temsil eden bireye, nesneye ya da sürece yansitırlar. (Erdoğan, 2011, s. 5)

Suç, kendi kendine oluşmaz, çatışmanın boyutlarına, etkinin şiddetine bağlı olarak ortaya çıkan bir tepkidir. Çatışma kuramcıları suç olarak tanımlanan etkinliğin fikir muhalefeti, itaatsizlik, şiddet ve sapma yoluyla yetkeye meydan okunmasından kaynaklandığını öne sürerler. Fakat elbette bu düzenin kabul edilemez gördüğü bir meydan okumadır ve derhal en şiddetli biçimiyle cezalandırılır. (Ruggiero, 2009, s. 25) Bileyici de müteahhitle, egemen olanın temsiliyle yaşadığı çatışmanın sonunda, değişen dünyada eski değerlere bağlı kalarak gösterdiği itaatsizliğini, gördüğü baskının sonucu olarak şiddete dönüştürür. Müteahhitin düzenine göre, o artık suçludur.

Yine Yüksek Gerilim kitabından "Adi Suçlu” öyküsünde de benzer bir mesele söz konusudur. Apandisit ameliyatı için hastaneye yatan "solcu" kadınla yanındaki yatakta kalan "düzenin kadını" - "burjuva kadın" arasında yaşanan çatışma öykünün temelini oluşturur. Birinci kadın; hapishanedeki arkadaşları, gördüğü işkenceler, arkadaşları "içerdeyken" "dışarıda" olmanın yarattığ vicdan azabı, gündelik hayata hiçbir şey olmamış gibi devam edilmesinin, yaşananları unutuyor olduğunu fark etmesinin verdiği suçluluk duygusuyla yorgun ve yeniktir. Yanındaki kadın ise sürekli ellerinin, tırnaklarının, ince belinin, iri göğüslerinin güzelliğinden, kocasının onu ne kadar güzel bulduğundan, doktorun bile gözlerini ne kadar beğendiğinden, kocasıyla her gece mutlaka dışarı çıktıklarından, briç partilerinden, büyük otellerin balo salonlarına kadar hep gezdiklerinden, yaptıkları Avrupa seyahatlerinden bahseder. Öyküde, birinci kadının düşünceleri iç konuşmalar olarak verilirken, düzenin kendisine yüklediği kadınlık rollerini layıkıyla yerine getiren ikinci kadının konuşmaları ise gittikçe artan bir dozda, hiç durmadan devam eden dış konuşmalar olarak verilir. Yazar, toplumda baskın olan, onaylanan, erkeğin arzusunun nesnesi olma rolünü kabul eden ve buna cevap veren, neredeyse sadece bir bedenden ibaret kılınmış, bir bedene indirgenmiş olan kadını, bir sınıfın materyalist, sığ ve yoz varlığının temsiline dönüştürür. Öyküde sürekli konuşan ve kendinden bahseden odur. İkinci kadın; bir uzantısı olduğu eril, kapitalist, burjuva gerçekliğinin, sürekli kendinden bahseden, kendisi dışında her şeye ilgisiz kalan, kesintisiz, bıktırıcı bir şekilde kendine gönderme yapan retoriğini somutlaştırır. Birinci kadın ise konuşamaz, temsil edilemez, dile dökülemez bir şiddetin, acının, sorgulamanın ve hesaplaşmanın içe dönmüş dilini temsil eder. Aslında her ikisi de bir monoloğu sürdürmektedir, aralarında bir iletişim yoktur; fakat düzen, ıslah edilemeyen kadının sesinin çıkmasına izin vermezken, uysal 
Adalet Ă̆goğlu'nun 12 Mart... $\quad$ DEU Journal of GSSS, Vol: 23, Issue: 2

kadının durup dinlenmeden konuşmasına müsaade eder. "Ellerim güzeldir, ellerimi beğenirim. İkide bir kımıldanıyorum. Kımıldanmamalıyım... Tırnaklarım uzun uzundur. Bakın, nasıl badem biçimi hem. (...) Zaten ben el ve ayağa çok düşkünüm... Ötekiler de el ve ayağa çok düşkünler. Öyle görünüyor. Süha’nın kızını sadece falakaya yatırmışlar. Acaba çabuk konuştu da ondan mı? Çocuk daha. On sekizinde. Bütün kötülükleri toptan öğrendiler. Bir çırpıda.” (s. 35) Düzenin onayladığı kadının konuşmalarıyla düşünme süreci kesintiye uğrayan, kendi iç sesini duyamaz hâle gelen birinci kadının düşünceleri, ikinci kadının bedeniyle ilgili söyledikleriyle istikrarsızlaştırılır ve hızlı çağrışımlarla arkadaşlarının gördüğü işkencelere dair bilinç akışı anlarına açılır. Düzenin sabit, değişmez, kapalı, kendinden emin, otoriter dilinin karşısına başkaldıranın sorgulayan, parçalı, düzensiz, hareketli dili çıkartılır. Birinci kadın, yanı başındaki bu eziyeti sonlandırmanın yolunu, kadının başına saksıyı geçirmekte bulur. Burada kadının başına atılan saksı da "Bileyici" öyküsünde olduğu gibi düzenin hiç durmadan ve baskılayarak, insana nasıl biri olması ve nasıl davranması gerektiğini dayatan sesine yöneltilmiş bir tepkidir. "ilk telgrafımı aldın $\mathrm{m}$ stop suçüstünde yargılandım stop kadının kaşının üstünde büyük bir yarık stop çiçek kabından stop adi suçlu olarak merkez cezaevine sevk edildim stop rahatım iyi stop" (s.46) Fırlatılan çiçek kabı ile kadının kaşında açılan koca yarık, düzenin "güzelliklerinin" birbirine vurulmasıdır. Düzenin görsellikten, cinsellikten, güzellikten başka bir şey yokmuş gibi yapan ve sadece bu dili üreterek dayatan söylemine bir isyandır.

Dolayısıyla suç ve suç işleme eğilimlerini bir isyan biçimi olarak ele almak da mümkündür. Suç bir anlamda toplumsal düzenin bozukluklarına karşı bir tepki olarak ortaya çıkar. Suçlular da düzenin "ötekileri” içinden çıkar, çünkü bu grupların düzen içinde kendi seslerini, kendi sözlerini ifade etme, duyurma, yayma ve savunma güçleri yoktur. Onlar da asla muhatap alamadıkları egemenin temsilcisine yönelerek tepkilerini ortaya koyarlar.

Tüm öykülerde vurgulanan asıl husus, suç ve suçlu yargılanırken, suçu oluşturan etmenlerin gözden kaçırılmasının büyük sorunlar yaratacağıdır. Suçun niteliği ne olursa olsun, cinayet, yaralama, tedbirsizlik sonucu ölüme sebebiyet verme vs. tüm bu suçların, ekonomik yapının belirlediği sınıf çatışmaları sonucunda ortaya çıkan, çevresel faktörlerce baskılanan bir kesim tarafindan gerçekleştiriliyor olması önemlidir.

Suça yol açan çevreye ve düzene, bilinçli ya da bilinçsizce yöneltilen bireysel tepkiler, düzen tarafından kolaylıkla etkisiz hâle getirilip savuşturulabilir, suçlular düzenin dışına kapatılabilirler. Engels, İş̧i Sınıfinın Durumu'nda bu tip suçları baskıya karşı etkisiz, kolayca bertaraf edilebilecek kişisel birer tepki olarak tanımlar. (Marksist Düşünce Sözlüğ̈̈̈, 2005, s. 90) Bu nedenle doğru tepkinin bilinçsiz ve bireysel değil, bilinçli ve kitlesel olması gerektiğini vurgular. Marksizm 
bireyi toplumsal bir ürün olarak görür. Amacı, şeyleşmiş toplumsal üretim biçimlerine son vererek onları "birleşmiş bireylerin gücüne" tabii k1lacak süreci anlamak ve bu sürecin içinde yer almaktır. Bu nedenle bireyin bilinçlenmesi ve bağlı olduğu sınıfla birleşmesi önem taşır.

Bireyin sınıfsal bilince sahip olmaması, kendi gerçekliğine yabancılaşmasının sonuçlarından biri, kişinin kendi haklarının farkında olmaması ve/ya kendi hakkını savunduğunu sanırken başkasının hakkını savunuyor olmasıdır. Sessizliğin Illk Sesi kitabında yer alan "Muz" öyküsü, sivil hayatta gittikçe soyutlaşmış sınıf ilişkilerini ve çatışmalarını görünür kılan öykülerden birisidir. "Hükümet değişse de birkaç bakanlık müsteşarı, birkaç genel müdür ve bazı genel müdür yardımcılıkları dışında hiç bir şeyin değişmediği” (s. 38) bir genel seçim sonrası, bakanlıkların birinde müsteşarken müşavirliğe atanan Baha Çamlıdere'nin, "sürekli boş duran" devlet dairesinde, diğer iki yaşlı müşavirin her gün dönüşümlü olarak birbirlerinin odasına ziyarete gitmekten başka bir şey yapmadığ 1 , bürokrasinin hantallığının ve işlevsizliğinin sergilendiği bir iki sahneden sonra, bu iki yaşlı müşavirden kendini kurtarmak için cumaları işe gitmemeye başladığı gösterilir. $\mathrm{Bu}$ sayede Baha, bir katının mülkiyetine sahip olduğu apartmanın, bir katının mülkiyetine sahip olmanın verdiği hakka ve güce dayanarak tüm işleriyle meşgul olmaya, apartmandakileri disipline etmeye başlar. Özellikle, cumaları apartmana gelen bir muz satıcısına kafayı takar. Kendi mesaisini iyice aksatan, artık işe hiç uğramayan Baha, muz yetiştiriciliği konusuna ilgi duymaya başlar. Uzun araştırmalar sonucu muz yetiştiriciliğinin tüm detaylarını öğrenir, muzun yetiştiği iklim koşulları, toprağın özellikleri, ürünü haşereden, sinekten koruma yolları, doğru gübre kullanma, işçi bulma, ürün toplama, nakliyesi, vergi gideri vs. derken Baha, seyyar muz satıcısının bu dertlerin hiçbirisini çekmediğini fark ederek sinirlenir: "Hazıra konuyor. Yüklen sat. Oh ne iyi! Dükkân kirası bile yok. Vergisi yok. Hiçbir rizikosu yok. Bir muz ağacı bile, yenisi gelirken kendini bitiriyor. Birini büyütürken kendi ölüyor. Seyyar muz satıcısına ne oluyor? Hiiiç.” (s. 47)

Kendisi hiçbir emek üretmeyen, en kısa zamanda muz üreticiliği işine girip çok para kazanmanın planlarını yapan, sadece sınıfsal pozisyonunun imtiyazıyla muz satıcısını yargılayan müşavir, bir kez daha apartmana giren muz satıcısıyla karşılaşınca, onunla doğrudan karşı karşıya gelmez; apartmanın kapıcısını satıcının üzerine gönderirken, onu tehdit ederek kışkırtır da. Elindeki en büyük kozu oynar, muz satıcısının olduğu gibi apartman kapıcısının da kaderi, müşavirin iki dudağının arasındadır: "Satıcıları göremezsin elbet. İşine son verdirteceğim. Kahve köşelerinde pinekle de gör. Defetsene şunu!" (...) Bu işi beceremeyeceksin sen. Her apartmanın kapıcısı ne yapıyor? Nasıl önlüyorlar seyyar satıcıları görmüyor musun? Bir sensin önleyemeyen. Böyle giderse çıkarırız, yok çaresi.” (s. 49) 


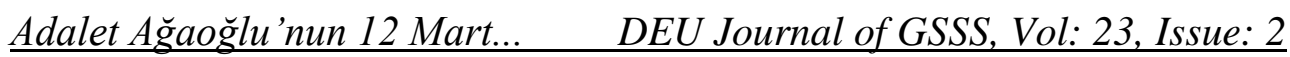

Müşavir olmasıyla devleti, kat sahibi olmasıyla özel mülkiyeti, muz yetiştirmeye dair planlarıyla özel sermayenin üretim ilişkilerindeki tahakkümünü temsil eden Baha, kapıcı ile satıcı arasındaki çatışmanın koşullarını da hazırlar. "Bileyici" öyküsündeki müteahhit gibi müşavir de yoksulu ve yoksulluğu kendi alanında görmeye tahammül edemeyerek karşısındakini "emek üretmemekle", "tembellikle", "kolaycılıkla" suçlar: "Çık dışar!!" diye bağırdı muz satıcısına. "Etme bey, ne zararım var sana? Bu da benim ekmek param." / "Muzu yetiştirenin ekmek parası o. Senin ekmek paran olsun istiyorsan git muz ocakları aç." / "Muz ocağı mı açayım?" / "Muz ocağı aç ya. Yevmiyesi otuz lira." / "Nerde açayım muz ocağını beyim?" / "Nerde açıllyorsa orda. Fuğla'da." (s. 51) Zenginliği çalışmakla, fakirliği tembellik, kolaycılıkla ilişkilendirmek elbette sermayenin kurduğu bir retoriktir ve kendi refahının arkasındaki sömürüyü gizleyerek kaynaklarını meşrulaştırmaya yarar.

Yine müteahhit gibi otoritesini onaylatamamanın öfkesini ortalığa saçıp tehditler savuran müşavir, sonunda iki yoksulu birbirine kırdırır. Her ikisi de ekmeğinin derdinde olan satıcı ve kapıcı, birbirlerini ekmeğine tehdit olarak görürler, görmeye zorlanırlar. İşini kaybetme korkusuyla muz satıcısına saldıran kapıcı, kavga sırasında satıcının darbesiyle başını beton duvara çarpar. "Bakkalın küçük çırağı, yerdeki iki patlak muza doğru ince bir kanın usul usul aktığını gördü. Bunu gördü diye olayın tek görgü tanığı sayıldı." (s. 52) Aslında düzen, ezileni sadece suç eylemi içinde görür, algılar; onu suça yönelten süreci ve bu sürecin gayrimeşru varlığınıysa görmezden gelir. Yoksul, bir başka yoksulun "gözlerinde" suçlandırılır. Yoksulun tanıklığı da eylemi de ancak burjuvanın düzeninin devam ettirmeye yarayacaksa görülecektir.

Burjuva devletlerinde resmî olarak kaydedilen suçların çoğunluğu, sosyoekonomik merdivenin en altındaki kişiler tarafından işlenmektedir. Bu durum fırsat eşitsizliği, maruz kalınan baskı, şiddetle ilişkili olmasının yanında, tutuklanma, yargılanma, hapsedilme gibi resmî kontrol mekanizmalarına karşı daha savunmasız durumda olmalarıyla da ilişkilidir. (Cohen, 1988, s. 47) Burjuva sınıfı tarafından gerçekleştirilen suçlar görünür hâle gelmezken, işçiler, emekçiler, lümpenler, yoksullar, orta sınıfa mensup küçük insanlar tarafından işlenen uyum ve karşı koyma suçları hep "görülür".

Romanlarında türün sağladığı imkânlarla daha detaylı ele almakla birlikte Adalet Ağaoğlu hikâyelerinde suç ediminde bulunan karakterlerin kişisel özelliklerini, iç dünyalarını, psikolojilerini vs. göstermekten çok onların sınıfsal pozisyonu, maruz kaldıkları toplumsal güç, baskı ve çıkar çatışmaları üzerinde yoğunlaşır. Fakat Yoksulluğu, eşitsizliği, sömürüyü, baskıyı ve bunlara bağlı olarak ortaya çıkan suç eylemlerini, doğrudan kapitalist sistemin bir sonucu olarak görür. "Eskiden, Bir Sabah..." öyküsünde anlatıc1-karakterin dediği gibi yasalar "büyük 
davalarda hep büyük burjuvadan yanadır ama böyle küçük davalarda da küçük burjuvadan yanadır." (s. 74) Dolayısıyla yazar, suçu oluşturan dört unsurun, devlet, toplum, suçlular ve kurbanlar (Marsh vd., 2006, s. 123) arasındaki ilişkileri görünür kılarak yüzeyde teşhis edilebilen, "tanık olunan" suç ediminin gerisindeki ilişkiler ağını ve bunun tüm sorumlularını ifşa eder.

\section{BÜYÜK KAPATILMA}

Foucault, hapishanelerin cezalandırma mekânları olarak 18. yüzyılda ortaya çıkmasının nedenlerini ekonomik ve siyasi koşulların değişimine bağlar. Bunun için, 18. yüzyılın sonundaki "köylü suçluluğu sorunu"nu örnek verir. Bu dönemde kısmen burjuvazi tarafından elde edilen, feodal yüklerden kurtarılan toprak mülkiyeti, mutlak bir mülkiyet hâline gelmiştir. Köylülügün elde ettiği veya koruduğu tüm hoşgörüler (tarlalar ekili değilken hayvan otlatma hakk1, odun toplama hakk1 vs.) şimdi yeni mülk sahipleri tarafından tamamen yasa ihlali statüsüne sokularak defedilmektedirler. Bu da halk arasında giderek daha da yasadışı hâle gelen veya eğer öylesi istenirse suç kapsamına da giren bir dizi zincirleme tepkiye yol açar: tarla çitlerinin kırılması, hayvan hırsılılı̆̆ veya öldürülmesi, yangın çıkartma, şiddet, cinayet vs. Çoğu zaman en yoksunların hayatla kalmalarını sağlayan, haklara yönelik yasadış1lı, yeni mülkiyet statüsüyle birlikte mallara yönelik bir yasadış1lık hâline gelme eğilimine girmiştir. Ve burjuvazi bu yasadış1lığa toprak mülkiyeti alanında iyi gözle bakmıyorsa da ticari ve endüstriyel mülkiyet alanında hiç tahammül edememektedir. Öyleyse cezalandırmak gerekecektir: cezalandırmak ve hapsetmek, 1slah etmek, sonrasında ucuz işgücü olarak kullanmak vs... (Foucault, 1992, ss. 104105) $\mathrm{Bu}$ sürece dair çözümlemesiyle Foucault, kapitalizm ile kapatma pratiği arasında bir bağ olduğunu ifade eder.

Kapitalizmin amacı bireyi üretim ilişkileri içinde kullanılabilir bir işgücü hâline getirmektir. Kapitalizm böylesi bir mantığı pratiğe aktarabilmek için bazı enstrümanlara ihtiyaç duymuştur. Bunlardan biri de hapishanelerdir. Fakat hapishanelerin mahkûmlar açısından eğitici, sslah edici ve tövbe ettirici yerler olma konusundaki "başarısı" tartışılır. Yazdığı Sefiller romanı, suç işleyenlerin toplum tarafindan kötü kişilere dönüştürüldüğünü iddia ettiği için tehlikeli bulunan Victor Hugo, mahkûmların hapishanelerde yeni suçlar tasarladıklarını belirtir. Çünkü mahkûmlar hapishanede sadece çıkacakları günün hesabını yaparlar ve hapishane koşullarına psikolojik olarak dayanmak için kendilerini reddedenleri reddetmenin bir yolunu ararlar. (Ruggiero, 2009, s. 202) Bu ret, uysallaşmanın, evcilleşmenin, "suçun" kabulünün reddidir. Bununla birlikte Marx, Nüfus, Suç ve Yoksulluk'ta, ceza kanununu şöyle bir okumanın, onun suçları cezalandırdığı gibi yarattı̆̆ını da gösterdiğini iddia eder. (Marksist Düşünce Sözlüğü, 2005, s. 560) 


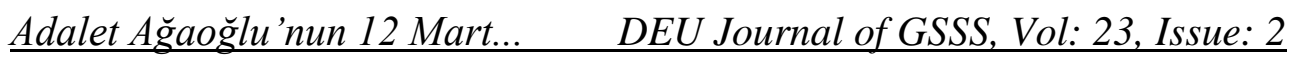

“Yüksek Gerilim” öyküsünde Kadir Çiçek, kardeşini maktul, kendisini katil yapan düzeni tanır. O artık yüksek gerilim hattını da, o yirmi beş mumluk ampulü de "görmektedir": "Kadir Çiçek, koğuşta gözünü bu soluk 1şıktan hiç ayırmadı. Üşenmesiz, uzun baktı. Aylarca baktı: Işı̆̆ı iyice tanıdı. Tanıyıp beynine akıttı; gerildi. Her gün daha yüksek gerildi.” (s. 28)

Kadir, düzenin oluşumunun elverişli hâle getirdiği suç eylemini düzene karşı işlerken, bu eylem vesilesiyle tam ortasında durduğu ama farkında bile olmadığ düzenin gözünün içine bakmaya başlar. Suçun sonucu bir pişmanlık, vicdan azabı, yüzleşme değil, bilinçlenmedir.

"Yasemin İşçileri” öyküsünde ise hapse düşen sol görüşlü Kaya, görüş gününe gelen fakat bakanla buluşacağı için acelesi olan babasının "öyle olmadığını" söylerse kurtulabileceğine dair teklifini şiddetle reddeder. "Bizden bizim, kendimizin değil, Menderes'in hesabını soruyorlar. Menderes asıldığında ben on yaşımdaydım. Bunu en iyi sen bilirsin baba" (s. 120) sözleriyle Kaya, yargılamanın ve iktidarın meşruiyeti ile birlikte "suçlu" tanımını ve iktidarla uzlaşmayı reddeder. Tek hissettiği duygu, "çocukların önünde babasından ötürü duyduğu utanç”tır. (s. 152)

Hapishanelerin bir başka gerçekliği ise işkence sorunudur. Hapishaneler çok zaman suç ile ceza arasındaki orantısızlığın ortaya çıktığı yerler olarak görülür. İşkence, her dönemde uygulanan bir tekniktir ve değerlendirilebilen, kıyaslanabilen, hiyerarşik hâle getirilebilen bir acı üretimidir. İşkencenin halka açık biçimde bir gösteri hâlinde sunulduğu zamanlarda suç ile cezanın orantısızlığı nedeniyle halkın tepkisini çekmeye başladığında iktidarlar, infazın şeklini değiştirerek amacın devamını sağlar. Ceza artık seyirlik olmaktan çıkıp yeni bir usul hâline gelir. Bu yeni usulde cezalandırma, sürecin en gizil parçası olur. Yani şiddet bir tiyatro şeklinde değil, bürokrasi içinde gizli bir biçimde uygulanacaktır. (Saygılı, 2004, s. 190)

Foucault Hapishane'nin Doğuşu'nda, hapishanenin nasıl bir disipliner aygıt olduğunu açılklarken amacın "bireyin bedenen ve ruhen uysallaştırılması" olduğunu belirtir: “(...) bireyin tüm veçhelerini, fizik olarak terbiye edilmesini, çalışmaya yatkınlığını, gündelik ahlaki hâl ve gidişini, eğilimlerini kendine iş edinmelidir; hapishane, hepsi de belli bir uzmanlaşma içeren okul, atölye veya ordudan daha fazla" her alanda disiplinli"dir. Üstelik hapishanenin dışarısı ve boşluğu yoktur; görevi tamamen sona ermedikçe kesintiye uğramaz; birey üzerindeki etkisi kesintisiz olmalıdır. Aralıksız disiplin son olarak da mahpuslar üzerinde adeta tam bir iktidar sağlamaktır; kendi iç baskı ve cezalandırma mekanizmaları vardır: müstebit disiplin. Diğer tüm disiplin düzeneklerinde bulunan usulleri en yüksek yoğunluklarına taşımaktadır. "Yozlaşmış bireye yeni bir biçim dayatmak üzere, en güçlü makine olması gerekir; eylem tarzı eksiksiz bir eğitimin zorlamasıdır." (Foucault, 1992, ss. 295-296) 
12 Mart anlatılarının temel özelliklerinden biri işkence sorunudur. İşkence hem kamuoyunun 12 Mart'1 algılamasında hem de edebiyatın konuyu ele alış biçiminde asıl öğelerden biri hâline gelir. 12 Mart sürecinde yaşananların kamuoyuna anlatılması konusunda ağırlıklı olarak öne çıkan yöntem, suçlu ilan edilenlerin baskı rejimi tarafından uğradıkları haksızlıkları, insanlık dışı muameleleri kamuoyuna duyurmak, örtbas edilen şiddet ve işkenceyi gözler önüne sermektir. Böylece bu metinler, birer tanıklık ve hatta itham belgesi niteliği taşırlar. Suçlu ilan edilenlerin suçsuzluğunu vurgulamak için, devletin suçluluğunun altı çizilir. Bu hâliyle de işkence, akıldışı bir uygulama olarak algılanır. (Belge, 2006, s. 120)

“Adi Suçlu” öyküsündeki sol görüşlü kadın, hapishanede işkence gören arkadaşlarını düşünmekten kendini alamamaktadır. “Ayşe'yi öteki tutukluların yanına getirdiklerinde sağ eli çalışmıyormuş. Tabanı parçalanmış. Böbrek sancısından kıvranıyormuş. Falakaya bağlamışlar. Copla dövmüşler. Islak yere atmışlar. Bluzunun yakasını açmışlar. Gögüslerinin ucuna elektrik tellerini dayamışlar. Tellerin birer ucunu da. . . Sonra konuş demişler... O da. . . (. . .) Onu, orasından burasından kan fışkıracak denli dövdüklerine inanmıyor ki. Başkasının kanı oğlunun gömleğine bulaştı sanıyor. (. . .) Nur'u tavanında peçete büyüklüğünde buzlu camı olan genişçe bir hücreye almışlar. Gece saat dokuzdan sonra bir nöbetçi polis, ikide bir buzlu camı sıyırıp açıyor, başını aşağıya uzatarak 'Arkadaşın kız çıktı, kadın yaptık. Seni de yapalım mı?' diyormuş. O zaman tek çıkar yol bayılmakmış. Baygınken hiçbir şey duymayacağın için işleme ara veriyorlarmış.” (s. 30, ss. 3445).

Bütün bu akıldış1lığın vurgulanmasına rağmen, devletler bir yandan hukukun kusursuz vücut bulmuş hâli olarak incelenirken, diğer yandan ampirik varlıklar olarak görülürler. Yani kendi varlıklarını devam ettirmek için bunu sağlayacak uygulamalar ve ortakları, yasal olsun olmasın şiddetle arayan düzenlerdir. Bir başka deyişle devletler yalnızca hedef ya da arabulucu değil fail olarak da düşünülür. (Ruggiero, 2009, s. 229) Dolayısıyla dünyanın en gelişmiş burjuva sınıfları da kavganın kızıştığı, iktidarlarının ciddi tehlikeye düştügü dönemlerde işkenceye başvururlar. Bu bakımdan işkence akıl ve insanlık dışı bir şey değil, gayet çağdaş bir “teknik” olarak varlığını sürdürür. (Belge, 2006, s. 127)

\section{DIŞARIDA OLMANIN AZABI: "HİÇ KİMSE MUTFAĞA AMPUL ALMAYI UNUTMAZ"}

12 Mart sürecinde yaşanan şiddetin boyutları sadece fiziksel olan üzerinden anlatılmaz. Suçlu olarak tanımlananların suç olarak görülen eylemleri, onları bu eylemlere götüren sürecin içsel boyutları, suçlu yakınlarının yaşadıkları korku ve gerilimler, kamuoyunun kendini koruma mekanizmasıyla olan bitene göster(me)diğ i 
Adalet Ăgaoğlu'nun 12 Mart... DEU Journal of GSSS, Vol: 23, Issue: 2

tepki gibi pek çok konu, toplumsal bir kaosun, bir cinnet hâlinin bireylerin iç dünyalarına yansıma şekilleriyle gösterilir. Sadece fiziksel değil, psikolojik şiddete de maruz kalmıştır insanlar ve bu şiddetin de sonuçları daha az korkunç değildir.

"Adi Suçlu" öyküsündeki sol görüşlü kadın, bir yandan yanındaki kadının durmadan firlattığı cümlelerden kendisini korumaya çalışıp, bir yandan işkence görerek hapishanede tutulan ya da sonrasında salıverilen arkadaşlarını düşünürken, bir yandan da hiçbir şey olmamış gibi gündelik hayatına devam etmekten duyduğu suçluluk hissiyle yüzleşir. "Yavuz'un tırnakları biraz iyileşmeye başlamış (...) Çıkınca börek yapsam, Nur'la göndersem. Tırnaklarını nasıl da yakmışlar. Morlukları hâlâ duruyormuş. (...) Biz dışarıdakiler de...İşte ancak kör bağırsağa irin toplamayı biliyoruz. Çıkar çıkmaz Yavuz'a börek yapayım. İçimizi başka nasıl sustururuz?" (s. 31)

Hastaneden çıkar çıkmaz hapishanedeki Yavuz'a börek gönderecek olan kadın, içerideki bir başka işkence gören arkadaşı Behçet'e "bu kez kek gönderemedi[ğinden] ama kazağını örüp yetiştirdi[ğinden], arkadaşı Seyfi'nin hapisteki arkadaşı Nihat'a, onu hiç tanımamasına rağmen, içeriye dayanabilmesi için hep gönderdiği selamlar"dan bahseder. (s. 34) Dışarıda kalanların içlerindeki sesi susturabilmelerinin bir yolu, içeridekilerle bu şekilde de olsa iletişim kurmaktır. Bunun bir diğer yolu da olanları unutmadıklarını, varlıklarıyla sürekli hatırlatarak direnmek ve meydan okumaktır. Gündelik hayatın devamı, bir yenilgi değil ancak bir direniş ve karşı koyuş hâlini alırsa ruhlardaki çalkantıyı biraz olsun dindirebilecektir. "Yüzler hep gülerken suçüstü yakalanmış gibi oluyor. Oysa kasten gülünüyor. İçten gelmese de gülünüyor. İnadına. Bir çeşit direnme seçildi böylece." (s. 32) Ama bu, o kadar da kolay olmayacaktır. Gündelik hayat, dışarıda olan herkesi kendi girdabına çekmekte çok da zorlanmayacaktır. "Biz de birçok şeyi unutur olduk. Yarın hiç hatırlamayacağız diye korkuyorum. O zaman, ölenler sanki boşuna ölmüş olacaklar. Bunu böyle düşünmeye bile hakkım yokmuş gibi geliyor. Evet. Yok hakkım." (s. 38)

Dışarıdakiler, sürekli olarak dışarıda kalmanın huzursuzluğuyla baş etmenin yollarını ararlar. Gülmenin bile vicdani bir suç olup olmadığı tartışılır, içeridekilere mektup yazarken söze geçmiş olsun diye başlamanın anlamsız olup olmadığı üzerine kafa yorulur, içeridekilere selam göndermenin onları daha da öfkelendirip öfkelendirmeyeceği üzerine düşünülür... İçeridekilerle aynı fikirlerde, aynı inançlarda, belki de aynı eylemlerde bulunmalarına rağmen dışarıda kalmış olmanın azabı, fiziksel azabın yerini alır. İçeridekilerin suçluluğu, dışarıdakilerin suçluluk duygusudur. "Dışarıda kalmışsak, dışarıda kalmalıyız. Ne de olsa bizlerin ağzına emniyeti açık bir tabanca sokulmadı. (. . .) Durmadan azalan bir şeyin yerini durmadan artarak alan bir şey var: Her gün biraz daha suçlu olmak. Onlar da bunu bilemeyecekler." (s. 41) 
"Gün Üç Dakika" öyküsünde, hapisteki yakını için altı aydır dolaşan genel af söylentilerini her gün takip eden anlatıcının, aynı zamanda gündelik hayatın rutini içinde kaybolmama savaşını nasıl yürüttüğü ve içindeki çatışmalarla nasıl baş etmeye çalıştığı da görülür. "Epeydir çoğumuz sanki yataktan yanlışlıkla kalkıyoruz. Ağzımızı çalkalıyoruz. Bir önceki acısını yıkıyoruz. Ağzımızı çalkalamakta bir yanlışlık buluyoruz. (. . .) Dişarı çıkmıyoruz. Dışarda bir şeylerden eksik kaldığımızı duyuyoruz. Dışarı çıkıyoruz. Dışarda olduğumuz için eksildiğimizi duyuyoruz." (s. 175).

Dışarıda kalanın gündelik hayata tek direnme biçimi hafızadır burada da. Ama o hafızanın da malullüğünün farkındadır dışarıdaki. Bunun kaçınılmazlığını bilir. "İçerde tek yakını olan $\mathrm{m} ı$ hiç yakını olmayan mı çabuk unutur? Hiç yakını olmayan da tek yakını olan da hepsine yakın olan da hiçbirine yakın olmayan gibi mutfağa ampul almayı unutmaz." (176) Gündelik hayat, kendi rutini, tekrarları, üretimi içinde kendisini sürekli yenilerken kişileri de bu rutine bağımlı hâle getirmekte zorlanmaz.

Sessizliğin İlk Sesi kitabındaki "Kulak T1kaçları" öyküsü de karakterin, toplumsal sorumluluklarıyla bireysel kaygıları arasındaki gerilimi ve yaşadığı suçluluk duygusunu ele alır. Öykü boyunca; sağ ve sol görüşlü öğrenciler arasında çatışmaların yaşandığ 1 , kardeşinin de bu çatışmaların içinde olduğunu anladığımız, art arda bombaların patladığ 1 bir ortamda, anlatıcının, yaşadığı kaygı-yoğun süreçte direnç gösterme-dayanma çabası ile kendini tüm bu olanlardan soyutlayıp "tek bir gece deliksiz uyuyabilme" ihtiyacı arasında gerilimli salınışını izleriz. Arkadaşının dışarıdaki sesleri duymadan, rahatlıkla uyuması için verdiği kulak tıkaçlarıyla ilişkisi, anlatıcının yaşadığı psikolojik süreci somutlaştırır. Anlatıcı, tıkaçları takınca her şey susar:

"Yalnız kulakların değil, kafan da susuyor. Yüreğin bile. İçinden hemen kimseyle kavga etmiyor, kimselerden hesap sormuyorsun; o çocukları öyle öyle kimler vuruyor, kimler dövüyor, o yalanları, bu ikiyüzlülükleri, şu pislikleri nasıl üretiyorlar böyle leş üstünde üreyen sinekler gibi demiyorsun işin en kötü yanı ve uykusuzluktan tükenip gitmekten iyidire getirip kıvranmiyorsun kuru kuruya ve utana sıkıla, nasıl alt edeceğiz bütün bunları, nasıl başa çıkacağız, nasıl hak edeceğiz güzel uykuları diye diye (..) dişimle tırnağımla büyüttüğüm, okumalara gönderdiğim kardeşime nasıl bir şeyler olmamış olabilir, iyi midir, iyi midirler, yürüyün kardeşler, yürüyün, yürüyün ulanlar, yürüyelim böylecene ve yürüyormuşsun sanki de damarlarının patır patır atması, bir evecenlikle yüreğinin kabarıp kalkması duruyor." (ss. 172-173)

Geceleri kulak tıkaçlarıyla susturduğu dış dünyayı unutup uykuya kavuşabilen anlatıcı, gün içinde o sesleri tüm şiddetiyle duymaktan kaçamaz; hatta dışarıda olduğu bir an, büyük bir şiddet ve sarsıntıyla patlayan bir bombanın etki 
Adalet Ă̆goğlu'nun 12 Mart... $\quad$ DEU Journal of GSSS, Vol: 23, Issue: 2

alanı içinde yer alır. "(...) dağılıp saçılan camlardan, beton kırıklarından, tahta parçalarından daha uzak noktalara sıçrayıp saçılanların" ortasında, kulak tıkaçlarını özler karakter: "Kulak tıkaçlarını özledi. Ki buna insan demişler. Özledi o tıkaçları." (s. 176) Politik-vicdani sorumluluk ile bireysel hayatta kalma çabası arasında çatışmalarının üstesinden gelemeyen anlatıcı, her iki durum, sosyalist bilinçlilik ile bireysel öznelliği arasında savrulup durur. Kardeşini hatırlamak, tüm kardeşlerini unutmamak için patlamadan sonraki üç gün kulak tıkaçlarını kullanmayı reddeden, diğer yandan gittikçe baskın ve ağır hâle gelen uyku isteğine direnemeyen, uyuyabilmek için tıkaçları taktığında karşısına ona hesap sorarcasına bakan kardeşinin hayali dikilen, karakter; girdiği kısır döngü içinde sorumluluklarıyla, duyarlılıklarıyla, bencillikleri hatta doğası arasında sürekli bir savaş içinde deneyimler kendini. Politik olarak, duygusal olarak yakın olduğu insanların ödediği bedellerin aksine, korunaklı alanında olmanın verdiği azapla, en azından onları hatırlamak, unutmamak, gündelik hayatı olağan akışından çıkararak dondurmak yoluyla baş etmeye çalışan karakter, bunu da tam olarak başaramaz. Aslında tüm olanlar içindeki kendi ironik-çelişkili pozisyonunun başından beri farkındadır, kendini tüm bilinçliliğiyle kavrar, kendi durumuna yabancılaşmıștır ve en sonunda kulak tıkaçlarını pencereden dışarı atarken bile bunun farkındadır, tıkaçları fırlatırken dahi "içini bir yazıklanmanın, ince bir hayıflanmanın yalayıp durmasını engelleyemez". "Onun bütün yiğitliği bu kadar. Kulak tıkaçlarından sevinmesiz cayabilecek kadar." (s. 178)

Aynı kitapta yer alan, "Yüksek Gerilim” öyküsündeki olayların, Kadir'in eşi Sakine odağında anlatıldığı "Bi Sevmekten... Bi Ölümden..." öyküsünde de eşini hapse, kayınbiraderini mezara gönderen Sakine'nin, asıl suçlular kendini hukukivicdani düzlemde aklamanın bir yolunu bulurken, yaşadığı suçluluk duygusu yansitılır. "Kocasının sağ olduğunu, tutulup kente götürüldüğünü anlar anlamaz, Hasan! Kömürleşmiş gövdesi ordan indirilip yere uzatılmadan önce 'şükür' demiş olmalı. (...) Ayışı̆̆ 1 Hasan'ın kararmış gövdesi üstüne çiselerken 'şükür' demiş olmalı, şükür babaları değilmiş elektriğin çarptığı." (s. 96-97). Sakine, bir andan daha kısa süre içinde gelişen bu duygudan dolayı kendini hiç affetmez, kardeşi gibi sevip büyüttüğü Hasan'ı koruyamadığ düşüncesi suçluluk duygusunu derinleştirir. Sakine, asıl suçluları görmez, aksine suçu içselleştirir, kendini sorgular. Üstelik Arif Amca'nın "her bakışı, her duruşu, her sözüyle Sakine'yi suçlar gibi” (s. 94) davranması, onun suçluluk duygusunu baş edilmez hâle getirir.

Peki kimdir bu amca? Cenazede ortaya çıkıveren taşeron firma sahibi Arif Amca, "Koyu renk elbise, koyu renk fötr şapka, beyaz gömlek ve kurşun rengi kravat"1yla (s. 94) köylülerin yabancı bir varlık gibi hayranlıkla-çekinmeyle izlediği; üzüntüsünü "iflas etsem böyle yıkılmazdım" (s. 95) sözleriyle, cenaze günü hemen çekip gitmesini "işlerini yüzüstü koyup gelmesiyle" ifade eden; Hasan için hatim indirilsin, mevlüt okunsun, mezarı yaptırılsın diye lütfedercesine para bırakan, fakat 
asıl olarak taşeronluğa başladığı zaman Kadir'i bir kı bulup evlendirerek masrafindan kurtulan, Sakine'nin hastalığı zamanında bakmakta zorlandığı oğlu, kendi yeğeni Sefer'i yanına almayı reddeden, Hasan'ın yanında çalışma isteğini kabul etmeyerek geri gönderen, bir kardeşinin hapse, diğerinin mezara gitmesine yol açan müteahhit firmadan iş almak için cenaze başında pazarlık yapan biridir Arif Amca. Fakat tüm olanlarla ilgili hiçbir sorumluluk almaya niyeti yoktur. Onların kaçtığı-örttüğü suçları, Sakine gibilerin sırtına yüklenir. Fakat Sakine de tüm yaşananlardan sonra, Kadir gibi, tanır çevresini, her şeyi ve herkesi. Öfkesi Arif Amca kadar onun karşısında el pençe duran köylüye de yönelir ve yükselir yavaş yavaş: "Günlerdir içine çöreklenen o sinsi, devinimsiz ağırlık kök saldığı yerde bir iki sallanıp kütürtülerle çatırtılarla sökülüyor sanki. Bir deprem, bir firtına öncesi. Sezilir sezilmez ilk kırıntı, tornacının karısıyla duvarcınınkinin Arif’in önünde ezik büzük duruşlarını seçtiği an başlamamış mıydı? Öyle ya, Arif'ten önce onlara karşı bir öfke kabarmamış mıdı içinde?” (s. 106)

Bahsettiğim öykülerin tamamında yazar, politik, ekonomik, toplumsal çatışma ortamının şiddetiyle kuşatılmış bireyin insani-vicdani sorgulamalarına odaklanır. Karakterlerin "bir şey yapma" arzusuyla "bir şey yapamama" gerçeği arasında; politik-sınıfsal-ailevi "yakınlarının” uğradıkları şiddete, ölümlere, felaketlere karşın insanın kendi konumundan, duygusundan utanma, yaşamı dondurma arzusuyla gündelik hayat tarafindan ele geçirilme, doğası tarafındandoğası gereği o kaçınılmaz bencilliğine geri döndürülmesi arasında yaşadığ 1 gerilimleri sergiler. Kimsenin üstlenmediği "suç", sürekli karakterlerin sırtına yüklenir hem hukuk sistemi hem asıl müsebbibler hem de en çok kendileri tarafindan.

\section{SONUÇ}

Adalet Ağaoğlu'nun öyküleri üzerine yapılan çalışmalar ana hatlarıyla; yazarın metinlerinde ironiyi bir eleştiri yöntemi olarak nasıl kullandığını tartışan, ${ }^{4}$ kentleşme sürecinin hangi bağlamlarda ele alındığını açımlayan ${ }^{5}$, hikâyelere göstergebilimin yöntemleriyle yaklaşıp hikâyelerin temelindeki yapı-örgüyü ortaya çıkaran ${ }^{6}$ önemli çalışmalardır. Fakat Adalet Ağaoğlu'nun hikâyelerinde karakterlerin suç ile ilişkisini, suçun ve suçlunun sınıfsal bağlamını, toplumsalbireysel süreçlerini ele alan bir araştırmaya rastlanmamaktadır. Bu yazı, hikâyelerde

\footnotetext{
${ }^{4}$ Betül Coşkun, “Adalet Ağaoğlu'nun Hikâyelerinde Bir Eleştiri Vasıtası olarak İroni”, A.Ü. Türkiyat Araştırmaları Enstitüsü Dergisi, sayı: 49, 2013, ss. 145-170.

${ }^{5}$ Ayşe A. Dinç, Sezai Coşkun, “Adalet Ağaoğlu'nun Hikâyelerinde Kentleşme”, Süleyman Demirel Üniversitesi Sosyal Bilimler Enstitüsü Dergisi, 2013/2, sayı: 18, ss. 135-155.

${ }^{6}$ Hilmi Uçan, “Adalet Ağaoğlu'nun Yüksek Gerilim ve Bi Sevmekten... Bi Ölümden Adlı Kısa Öykülerinin Göstergebilimsel İncelemesi”, Afyon Kocatepe Üniversitesi Sosyal Bilimler Dergisi, cilt 1v, sayı: 1, 2002, ss. 64-76.
} 
Adalet Ağaoğlu'nun 12 Mart... DEU Journal of GSSS, Vol: 23, Issue: 2

karakterlerin farklı biçimlerde karşı karşıya geldiği suç, suçluluk, suçlanma, kapatılma deneyimlerinin nasıl ele alındığını inceliyor. Adalet Ağaoğlu 1970'lerde yazdığı roman, öykü ve tiyatro oyunlarında 12 Mart döneminin askerî, politik, toplumsal koşullarını, çatışma ve şiddet ortamını, tutuklama süreçleri, hapishane koşulları ve işkence sorununu yansıtırken, tüm olanları, bunlara tanık olan veya doğrudan yaşayan bireyin, bazen işçi-emekçi sınıfindan bazen sol görüşlü, sol aktivist çevrelere yakın bulunan fakat olayların faili olmayan bireylerin, iç dünyası ve psikolojisindeki yansımalarına odaklanarak ele alır. Özellikle bu dönemde kaleme aldığı iki öykü kitabı, Yüksek Gerilim ve Sessizliğin İlk Sesi kitaplarında, iktidarı, hukuk sistemini, suç olgusunu tartışmaya açarak eleştiren metinler yer alır. Suçun tanımını ve kapsamını belirleyen kanunların meşruiyetini, adi suç ve siyasi suç gibi tanımlamaların sonuçlarını, suçun oluşumunun sınıfsal kaynaklarını tartışan metinlerde mevcut hukuk sisteminin suçlu ilan ettiği kişilerin, insanı ve vicdani değerlere de yaslanan bir değerlendirmeyle okur nezdinde masumiyetlerinin onaylanması amaçlanır. Perde arkasında gizlenen asıl suç ilişkilerinin su yüzüne çıkartılması ve asıl suçluların okur tarafından teşhis edilmesi sağlanır. Bununla birlikte burjuva devletinin iktidarı, araçları, yöntemleri açığa çıkartarak ahlaki, vicdani ve hukuki dayanaklarından yoksun bırakılır. Böylece bütün meşruiyetini kaybetmiş bir burjuva devletinin iktidarına karşı çıkmak sadece gerekli değil; doğal ve kaçınılmaz bir tutum olarak da işaretlenir.

Bununla birlikte, yaşananların açık-somut mağduru olmayan, hatta korunakl1-konforlu gündelik hayatının dışına çıkmadığını gördüğümüz, sol görüşlü, sol çevrelere yakın, aktif çatışma ortamının içinde yakınlarının bulunduğu anlaşılan, zaten sosyalist, devrimci bireylerin hepsine ideolojik yakınlığından dolayı duygusal bir yakınlık da duyan anlatıcının da iç çatışmalarına ve yoğunlukla deneyimlediği suçluluk duygusunun aktarımına metinlerde şahit olunur. Dışarıdaki şiddetli çatışma ortamına bazen direnme bazen yok sayma edimleriyle cevap veren, yaşananları hem hatırlama hem unutma salınımında mücadele eden, sosyalist idealleri ile doğalbencil kayg1 ve ihtiyaçları arasında bocalayan, hapishanedeki yakınlarının, dostlarının, ülküdaşlarının gördüğü işkence haberleri karşısında dışarıda olmayı utançla deneyimleyen anlatıcı için nihayetinde yaşanan çatışmanın şiddeti, gerçekleştirilen her türlü edimi anlamsız kılacak kadar yoğunlukla kavrar insan psikolojisini ve anlatıcıyı bir edimsizliğe iter. Anlatıcı herhangi bir sözünü ve edimini anlamlı kılmakta zorlanır, tüm yaşananlar içinde kendi ironik pozisyonunu kavrar. Bu süreçte belki de anlamlı k1lınabilecek tek şey, yazmaktır, anlatmaktır. Yazı yoluyla hafiza oluşturmak, tarihin yeniden kavranmasını mümkün kılmaktır. Adalet Ağaoğlu, bunu yapıyor. 
Dicle, E. DË̈ SBE Dergisi, Cilt: 23, Sayı: 2

\section{KAYNAKÇA}

Ağaoğlu, A. (2004). Sessizliğin ilk sesi. İstanbul: Alkım Yayınları.

Ağaoğlu, A. (2004). Yüksek gerilim. İstanbul: İletişim Yayınları.

Belge, M. (2006). Edebiyat üzerine yazılar. İstanbul: İletişim Yayınları.

Cohen, S. (1988). "Failures of criminology," Against criminology içinde (4653). New Brunswick, New Jersey: Transaction Publishers. (çev. Tuba Topçuoğlu), CHKD, Cilt: 2, Sayı: 1-2, 2014, 269-280.

Erdoğan, A.Ö. (2011). "Üst başlık suç alt başlık ceza: Edebiyatın adaleti". Varlik. Ocak, s. 4-8.

Foucault, Ml. (2000). "The birth of biopolitics". (editör. Paul Rabinow). Essential Works of Foucault 1954-1984. London: Penguin Books.

Foucault, M. (1992). Hapishanenin doğuşu. Ankara: İmge Kitabevi Yayınları.

Marksist düşünce sözlüğü. (2005). (yayın yönetmeni Tom Bottomore). İstanbul: İletişim Yayınları.

Marsh, I. vd. (2006), Theories of crime, Ed. Ian Marsh vd. New York: Routledge.

Ruggiero, Vincenzo. (2009). Edebiyat ve suç. İstanbul: Everest Yayınları.

Sağlık, Ş. (2009). "Yasakların açığa çıkarılma oyunu: Suç ve roman". Hece. Say1: 149. 64-78.

Saygıl1, A. (2004). "Mikro-iktidarın bir fiziği: Hapishane". Ankara Üniversitesi Hukuk Fakültesi Dergisi. Cilt: 53. Say1: 2., ss. 178-196.

Susam, A. (2011). "Suç ve edebiyat ilişkisi bağlamında nesne ya da özne olarak kadının temsili”. Varlık. Ocak, s. 26-31. 